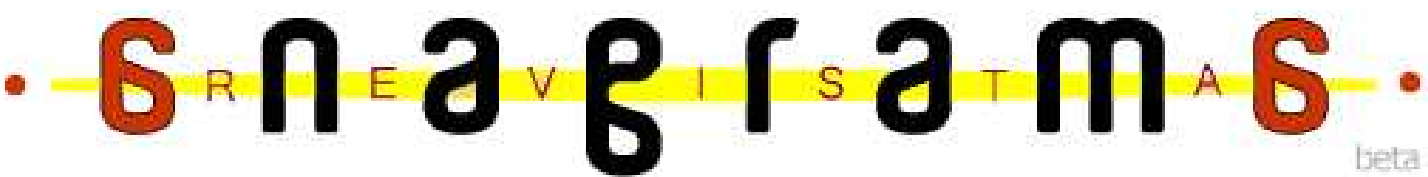

\section{Critérios de Publicabilidade: como os critérios de noticiabilidade são utilizados ou readaptados pela Reuista Superinteressante} Douglas Fernando Horbach ${ }^{1}$

\section{Resumo}

O presente trabalho tem por objetivo descobrir se, e em que medida, os critérios de noticiabilidade são utilizados ou readaptados por uma revista mensal, no caso do nosso objeto, a revista Superinteressante, da editora Abril. Para realizar esta pesquisa, partimos do pressuposto que uma revista mensal, à priori, não deveria se valer dos mesmos critérios que são adotados por meios jornalísticos mais imediatos, como jornais diários e até semanais, e que, por esse motivo, deveria dispor de critérios próprios, adaptados às características da mídia revista de edição mensal. Através da análise de seis exemplares da publicação, tendo como foco apenas as matérias com chamada na capa, devido à necessidade de segmentar o tema, chegamos a algumas conclusões que tornaram falsos nossos pressupostos. A revista faz uso de vários critérios de noticiabilidade (podendo ter qualquer matéria enquadrada em algum deles) usando principalmente o critério que julgamos que menos seria usado, o da atualidade.

Palauras-chaue: Noticiabilidade; Newsmaking; Revista.

Introdução

Os critérios de noticiabilidade, também conhecidos como valor-notícia, são conceitos subjetivos através dos quais os editores de qualquer meio jornalístico avaliam os dados que chegam até a sua redação e a partir dessa análise definem o que será ou não veiculado em seu meio de comunicação. Referimo-nos a conceitos "subjetivos", pois são

\footnotetext{
${ }^{1}$ Acadêmico do $8^{\circ}$ semestre do curso de Comunicação Social - Habilitação em Jornalismo da Universidade Federal de Santa Maria - Campus Cesnors.
} 
aplicados de acordo com a intenção ou avaliação dos editores dos meios de comunicação, perfil editorial do meio ou compromisso com anunciantes; enfim, muitos são os fatores que contribuem para que um meio de comunicação construa seus próprios critérios de noticiabilidade.

Apesar de serem tão subjetivos e variáveis de um meio para outro, devido ao fato de que são construídos através da interpretação dos jornalistas, Johan Galtung e Mari Holmboe Ruge elencaram, em 1965, em um estudo intitulado Structure os Foreign News (A estrutura das Notícias Estrangeiras), critérios que eles descobriram que eram coincidentes na maioria dos meios de comunicação que eles haviam analisado (KUNCZIK, 2002, p. 245). Dessa forma, esses dois pesquisadores conseguiram criar uma lista com os principais critérios de noticiabilidade, que serviram de influência para muitas pesquisas futuras.

Como já foi dito, esses critérios são utilizados pelas empresas jornalísticas para determinar o que é importante ou não ser veiculado naquele meio. O que acontece é que, pelo menos em teoria, esses conceitos deveriam ser unicamente utilizados para meios de comunicação mais imediatos, como jornais, telejornais e radiojornais, e dificilmente são encontrados aplicados à mídia revista, devido ao fato que geralmente esse meio não trabalha com fatos quentes, que estão em pauta na atualidade, e por isso não caberia para esse meio o termo "noticiabilidade", pois não trabalham com "notícias" como fazem os demais meios.

Com a falta de estudos sobre como os critérios de noticiabilidade podem (ou são) utilizadas pelas revistas, propomos a elaboração dessa pesquisa, que, utilizando a análise de textos publicados na revista Superinteressante, da editora Abril, revista mensal de curiosidades culturais e científicas, pretendemos descobrir como esses critérios de noticiabilidade são trabalhados nesse meio que, como regra, não trata com tanta frequiência, ou pelo menos não tem como proposta editorial, assuntos do tipo conhecido como "factuais", que são a base dos outros produtos jornalísticos.

Através de uma análise de conteúdo de seis exemplares (junho, julho, setembro, outubro, novembro e dezembro) do ano de 2008, pretendemos traçar um paralelo entre os critérios que são utilizados pelos meios jornalísticos que os utilizam, e como esses critérios se transformam e se readaptam para a mídia revista. Decidimos optar por esta amostra da revista por considerarmos que meio ano é tempo suficiente para entendermos como a revista trabalha, quais assuntos são mais recorrentes, e de que forma os repórteres 
trabalham as informações apresentadas em seu veículo de comunicação. Como foco dentre o universo de matérias presentes nestas seis edições, optamos por analisar unicamente as reportagens com chamada na capa, pois se supõe que seja na capa que esteja o que é considerado como o melhor da edição, seja em jornais, revistas, e até mesmo no jornalismo televisivo e radiofônico, na chamada "escalada".

Pretendemos descobrir dentre os critérios qual é o mais adotado pela revista que será analisada, através de análise qualitativa, e se ela utiliza algum dos critérios que tradicionalmente não se enquadrariam em seu perfil editorial. $\mathrm{O}$ objetivo geral deste trabalho, portanto, é entender a forma como as matérias publicadas em uma revista mensal, no caso a revista Superinteressante, podem se enquadrar nos padrões dos critérios de noticiabilidade utilizados pelo jornalismo diário, já que um não tem ligação com o outro, pois o jornalismo de revistas mensais não trabalha com notícias, mas sim com fatos mais elaborados e interpretados, que buscam o aprofundamento e não o "inédito".

Pretendemos, também, caso realmente os critérios de noticiabilidade não sejam utilizados por este meio jornalístico, tentar definir um conceito (ou conceitos), que englobem as características das matérias publicadas. Este conceito chamaremos de "publicabilidade", que seriam as características necessárias para a publicação de determinada matéria, caso a noticiabilidade não seja verificada em nossas análises.

\section{A Origem do newsmaking}

O newsmaking é uma teoria da comunicação, mais especificamente uma teoria do jornalismo. Ela trata da forma como os assuntos que ocorrem se transformam em notícias no mundo midiático, de que forma e por que esses fatos ganham o status de notícia. A hipótese do newsmaking teve sua origem tendo por base, e por que não dizer que surgiu para explicar, outra teoria: a do gatekeeping, como explica Hohlfeldt: "na verdade, os estudos em torno do newsmaking - que em uma tradução livre seria os fazedores de notícia ou a criação da notícia - surgiram exatamente em torno dos processos de gatekeeping verificados por Kurt Lewin já em 1947” (2008, p. 204). Nessa teoria, Kurt Lewin descreve que existem "portões" pelos quais passam as decisões "domésticas relativas à aquisição de alimentos para a casa", referindo-se a uma "pessoa que toma uma decisão numa sequência de decisões" (TRAQUINA, 2005, p. 150); no caso, quais alimentos devem ser adquiridos 
levando em consideração as necessidades da casa, visando uma melhor administração das despesas.

Essa teoria foi traduzida para o jornalismo graças às pesquisas de David Manning White, como explica Traquina: "White foi o primeiro a aplicar o conceito ao jornalismo, originando assim uma das tradições mais persistentes e prolíferas na pesquisa sobre as notícias" (2005, p. 149). A pesquisa de White, como citado por Hohlfeldt, para verificar a existência do gatekeeping, consistiu em uma análise das notícias que chegavam a um jornal médio norte-americano por meio de agências de notícias, que seriam analisadas por um jornalista com 25 anos de experiência, que ele chamou de "Mr. Gates", com a intenção de descobrir qual era a proporção entre quantas eram publicadas e quantas deixavam de ser publicadas pelo selecionador na edição do dia seguinte do jornal. Das 1333 notícias não publicadas, 800 foram por alegação de falta de espaço; 300 por já serem tratadas em outras matérias ou por não serem de interesse do público; 200 por falta de qualidade; e 33 por não estarem de acordo com os interesses do público tradicional do jornal. (HOHLFELDT, 2008).

Tendo por base esses números, White descobriu que apenas um décimo das notícias recebidas pelo jornal por meio de agências eram publicadas na edição do dia seguinte (HOHLFELDT, 2008), e como ele tinha anotado todos os motivos que levaram o gatekeeper a excluir nove décimos do material recebido, pôde chegar à seguinte conclusão:

A conclusão de White é que o processo de seleção é subjetivo e arbitrário; as decisões do jornalista eram altamente subjetivas e dependentes de juízos de valor baseados no 'conjunto de experiências, atitudes e expectativas do gatekeeper'. (Apud TRAQUINA, 2005, p. 150)

Para entender melhor essa conclusão, tomemos como apoio um exemplo: um assassinato em uma cidade do interior do Rio Grande do Sul e um assassinato na cidade de São Paulo, suponhamos que esse assassinato possua as mesmas características e praticamente as mesmas motivações, digamos, assalto seguido de morte por arma de fogo. Tal fato certamente figuraria entre as principais matérias de qualquer jornal interiorano na cidade em que ocorreu, por ser um fato extraordinário e provavelmente causar espanto e preocupação para os moradores locais; mas provavelmente não teria destaque em um grande jornal da capital paulista, tendo em conta o elevado número de casos desse gênero que ocorrem por lá todos os dias, no máximo mereceria uma pequena nota no boletim policial. É aí que entra a subjetividade, as "expectativas" do gatekeeper no processo de 
publicização das informações: no jornal pequeno, uma notícia dessas vende; no jornal grande de uma cidade enorme e conhecidamente violenta, não é nenhuma novidade.

Já para Robinson, "as decisões do gatekeeper são tomadas, menos a partir de uma avaliação individual da noticiabilidade do que em relação a um conjunto de valores que incluem critérios, quer profissionais, quer organizativos, tais como a eficiência, a produção de notícias, a rapidez" (Apud WOLF, 2003, p. 80). Isso quer dizer que os jornalistas seguem as normas da sua profissão na escolha das notícias e não utilizam juízos pessoais, fatores subjetivos. Essas idéias tomaram forma em 1976, com os estudos de McCombs e Shaw, e em 1977 com Hirsch. Esses estudos reanalisaram os dados obtidos por White em sua pesquisa e "apontaram a semelhança das proporções de notícias das diversas categorias utilizadas pelo serviço das agências e as notícias selecionadas por 'Mr. Gates"” (TRAQUINA, 2005, p. 151). Para Hirsch, as decisões tomadas pelo gatekeeper foram tomadas dentro de um padrão restrito de escolhas, nas quais vigoraram normas profissionais e não razões subjetivas.

Nesse caso, também pode ser utilizado o exemplo do assassinato posto acima. Caso o fato não seja sequer mencionado no jornal da cidade grande, pode-se alegar que ele não figura no cardápio de interesses do jornal, mas isso seria faltar com um dos deveres dos meios de comunicação, o de mostrar para o povo o que ele sozinho não conseguiria ver, além de desprezar um problema que é quase um caso de saúde pública das grandes cidades brasileiras. Mas, caso ele seja publicado em uma nota na página policial, é uma maneira de publicar sem dar muita importância ao fato, pelo menos ele está lá; e afinal, se os grandes jornais dessem muita atenção a todos esses fatos que ocorrem diariamente, não sobraria lugar pra mais informação alguma.

\section{Os Critérios de noticiabilidade}

Mas afinal, o que é notícia? Para Ricardo Noblat: "De forma simplificada, notícia é todo fato relevante que desperte interesse público, ensinam os manuais de jornalismo. Fora dos manuais, notícia na verdade é tudo o que os jornalistas escolhem para oferecer ao público" (2008, p. 31). Dizer que notícia é tudo que desperte interesse do público certamente soa muito vago, pois não é possível saber com certeza o que realmente é de interesse do público, e quem decide isso é o jornalista. 
Traquina define o conceito de noticiabilidade da seguinte forma:

Podemos definir o conceito de noticiabilidade como o conjunto de critérios e operações que fornecem a aptidão de merecer um tratamento jornalístico, isto é, possuir valor como notícia. Assim, os critérios de noticiabilidade são o conjunto de valores-notícia que determinam se um acontecimento, ou assunto, é susceptível de se tornar notícia, isto é, de ser julgado como merecedor de ser transformado em matéria noticiável e, por isso, possuindo 'valor-notícia'. (2008, p. 63).

Para Traquina, os critérios de noticiabilidade servem para que os jornalistas possam classificar com mais facilidade as notícias dentro de padrões pré-definidos e adotados como modelos pela "tribo jornalística", para que elas possam ser enquadradas em determinada categoria. É o mesmo conceito que adota Wolf, que define a noticiabilidade como "o conjunto de elementos através dos quais o órgão informativo controla e gere a quantidade e o tipo de acontecimentos, de entre os quais há que selecionar as notícias" (2003, p. 86). Mas isso pode gerar problemas, como descreve Noblat (2008, p.15): “Os leitores acham que o cardápio dos jornais está mais de acordo com o gosto dos jornalistas do que com o gosto deles. E que a visão que os jornalistas têm da vida é muito distante da que eles têm". Isso ocorre devido às distorções decorrentes da seleção equivocada dos assuntos que são escolhidos e eleitos como notícia pelos jornalistas. Já para Hohlfeldt (2008, p.208), os critérios de noticiabilidade são fatores verificáveis somente após terem sido concretizados, ou seja, são conceitos que só são aplicados depois que os acontecimentos ganharam o status de notícia, e servem para "reconstituir os valores que influíram na decisão de torná-la enquanto tal”.

Feitas estas considerações iniciais, partiremos agora para uma análise mais detalhada dos valores notícia. Para facilitar a sistematização dessa análise optamos por utilizar a classificação feita por Hohlfeldt (2008, p. 209-214), que subdivide os critérios de noticiabilidade em cinco categorias: categorias substantivas; categorias relativas ao produto; categorias relativas aos meios de informação; categorias relativas ao público; e categorias relativas à concorrência. Embora o autor se utilize de cinco subdivisões em sua categorização dos critérios, os únicos que atendem à demanda da nossa pesquisa são os dois primeiros, que são possíveis de se verificar exclusivamente analisando o produto, desta forma optamos por utilizar apenas as categorias substantivas e as relativas ao produto. Cada categoria é subdivida ainda por Hohlfeldt em diversos subitens, e embora uns sempre se sobreponham aos outros, sendo uns de uso mais corriqueiro e outros não tão 
utilizados e de difícil verificação, citaremos e analisaremos os que têm relação direta com o produto a seguir.

CATEGORIAS SUBSTANTIVAS: para Hohlfeldt (2008, p. 209), estes critérios ligam-se diretamente ao acontecimento, o que leva aquele fato a se tornar uma notícia por ele mesmo, sem outras influências que não sejam ele próprio. Subdivide-se em:

A. IMPORTÂNCIA: categoria que remete exclusivamente ao acontecimento, no qual o jornalista não tem a necessidade de avaliar os interesses de seu consumidor, são fatos que invariavelmente se tornam notícia:

I. Grau e nível hierárquico dos indivíduos envolvidos: diz respeito aos atores sociais que se envolveram no fato. Pessoas importantes/famosas despertam mais interesse para o acontecimento;

II. Impacto sobre a nação: diz respeito à importância que o fato representa perante o interesse nacional ou regional, como em questões relacionadas à soberania nacional, por exemplo;

III. Quantidade de pessoas envolvidas: obviamente, quanto maior o número de pessoas envolvidas no acontecimento, maior apelo este acontecimento terá, e consequentemente, maior será a sua noticiabilidade;

IV. Fatos que apresentem conseqüiências futuras: por questões de agenda, fatos que possam acarretar novos desdobramentos ou uma evolução futura tem uma maior aceitação quanto a um fato noticiável, pois ele tem condições de se tornar produto jornalístico novamente quando seus desdobramentos ocorrerem;

B. INTERESSE: Hohlfeldt (2008, p. 210) explica que "esta perspectiva apresenta situações menos claras e aparentes, resultando quase sempre de situações complexas". Nestes casos, o jornalista faz uma avaliação que parte da sua visão sobre seus consumidores, o que muitas vezes resulta em uma distorção entre o que o jornalista acha importante e o que o receptor acha importante:

I. Capacidade de entretenimento: busca chamar a atenção do receptor com base em fatos inusitados, inesperados. Pessoas em situações fora dos padrões da normalidade sempre chamam a atenção, sendo elas famosas ou não; o que vale nesta categoria é o poder de atrair o receptor pela distração que o fato lhe proporcionará. 
II. Interesse humano: notícias que busquem denunciar situações erradas ou a conscientização para algum problema se enquadram nesta categoria, mas o que acontece muitas vezes, de acordo com Hohlfeldt (2008, p. 210), é que muitas vezes, e facilmente, essa categoria se transforma em sensacionalismo, quando a desculpa do "interesse humano" se transforma em espetáculo.

III. Composição equilibrada do noticiário: para equilibrar os momentos de alegria e tristeza em um noticiário, busca-se uma forma de dosagem entre as matérias, desta forma, fatos que poderiam nem ser tão importantes acabam entrando no noticiário unicamente para deixá-lo mais equilibrado.

CATEgORIAS RELATIVAS AO PRODUTO: dizem respeito às condições de produção de material a partir de determinado fato. Estas condições podem incluir, por exemplo, a acessibilidade ao local onde o fato ocorreu, influenciando no tempo e no desgaste que será necessário para que uma equipe se desloque até o local, algumas vezes não compensando o deslocamento; diz respeito também à capacidade de tornar o fato dramático ou sua capacidade de entretenimento, que nada mais são do que a capacidade do fato em tornar-se "digerível" para o receptor. Entretanto, Hohlfeldt (2008, p.210) destaca que o fato pode ser tão importante que estes fatores podem tornar-se desprezíveis e ignorados.

I. Brevidade: o relato deve ser conciso o suficiente para se adequar aos padrões do meio no qual será veiculado, não podendo extrapolar os limites estabelecidos;

II. Condição de desvio da informação: vem da idéia de que notícia ruim é sempre melhor do que notícia boa, que o inesperado é sempre melhor que o fato rotineiro.

III. Atualidade: Hohlfeldt (2008, p. 211), explica que existe uma relação entre a disponibilidade da informação pelo meio e a possibilidade de divulgá-la junto ao público receptor. Tem a ver com o dead-line do meio e ter a notícia disponível dentro deste prazo, notícias que chegarem após este prazo ficarão de fora da edição, e posteriormente perderão o status de atual.

IV. Atualidade interna: diz respeito à organização da empresa jornalística. É a informação disponível, mas que não pode ser usada até pouco tempo antes de o fato ocorrer, caracterizando o que é conhecido como "furo" de reportagem. Utilizada no jornalismo investigativo, onde uma fonte presta um depoimento em "off" e exige que esta informação seja guardada até que o fato esteja prestes a ocorrer. 
V. Qualidade: o material deve ter um mínimo de qualidade que se enquadre nos padrões do meio no qual será veiculado para ganhar seu espaço, seja através do "ritmo narrativo, ao equilíbrio da ação dramática apresentada, àquele conjunto de informações disponíveis, às características do som, da imagem, do foco, à clareza da linguagem, etc." (HOHLFELDT, 2008, p. 212).

VI. Freqüiência: tem a ver com a facilidade de acesso à fonte ou ao local onde o fato ocorreu, gerando um planejamento de cobertura que pode se estender para diversas edições do meio;

\section{O Jornalismo de Reuista e a sua Relação com a noticiabilidade}

Existe muita diferença entre o jornalismo diário e jornalismo das revistas, tanto semanais ou mensais. Essas diferenças começam já pela linguagem. Em jornalismo diário, seja em ele em rádio, televisão ou impresso, ou até mesmo no jornalismo semanal impresso, típico das cidades pequenas, busca-se incansavelmente uma linguagem tida como "objetiva" e "isenta", linguagem essa que, aliás, é um dos fundamentos do jornalismo conhecido como padrão. Já o jornalismo das revistas se permite a expressar a opinião, que é o que muitas vezes o leitor habitual quer justamente saber sobre determinado assunto: a opinião da revista, a interpretação que os repórteres da revista fizeram sobre o fato. É o que explica Vilas Boas, quando diz que "neutralidade é uma 'pretensão' objetiva, comum no jornalismo diário... Já o texto de revista se propõe mais abertamente a interpretar o fato. Depois de 'assentada a poeira', vem a reflexão, a visão detalhada do contexto, a narrativa instigante e atraente" (1996, p. 14). O papel das revistas está mais inclinado a interpretar do que a simplesmente informar - isso quem faz é o jornalismo diário.

Por esse motivo, as revistas não dispõem dos mesmos padrões de noticiabilidade dos meios jornalísticos diários, pois noticiabilidade está intrinsecamente relacionado à produção de notícias, palavra que designa "novidades"; as revistas geralmente não trabalham com novidades, na maioria das vezes trazem fatos "frios", ou seja, notícias que já foram trabalhados pelos outros meios durante a semana ou o mês, mas de uma forma mais aprofundada. De acordo com Vilas Boas "nas revistas de informação geral, o melhor caminho para redigir não é aquele recomendado pelo manual de um grande jornal diário. A 
'escrita' também não pode ser aleatória, sem uma análise do fato e suas consequiências" (1996, p. 15). De forma simplificada, o que é notícia em um jornal diário pode não se tornar uma matéria em uma revista, e a linguagem utilizada por um jornal é muito diferente da utilizada em uma revista. Em outro trecho de seu livro, Vilas Boas explica:

(A) obrigação do jornal diário e do telejornalismo é dizer o que está acontecendo. Os jornais tendem a particularizar o fato, tratando-o com imediatismo e pulverizando suas conseqüências. $\mathrm{O}$ jornal diário tem de noticiar as exceções, ou seja, tudo aquilo que escapa à normalidade. Já a revista semanal de informações deve tratar o conceito de notícia de um modo mais amplo, estabelecendo um contexto maior. (1996, p. 75).

Para Scalzo, "não dá para imaginar uma revista semanal de informações que se limita a apresentar para o leitor, no domingo, um mero resumo do que ele já viu e reviu durante a semana" (2006, p. 41), para a autora, se a revista vai tratar dos assuntos que foram notícia durante o mês ou a semana, é sempre necessário um aprofundamento sobre o tema, "descobrir o que ninguém sabe sobre ele" (2006, p. 41). Esse é um problema que se tornou inerente ao meio, o da necessidade do aprofundamento.

Nas revistas quinzenais e mensais, esse problema é ainda mais evidente. Além de se distanciar ainda mais do tempo real da notícia, a publicação de periodicidade mais larga obriga-se a não perecer tão rapidamente, a durar mais na mão do leitor. É por isso que a notícia 'nua e crua' nunca teve lugar de destaque em revistas. (SCALZO, 2006, p. 42).

É por esse motivo que as revistas mensais não costumam trabalhar com fatos recentes, trabalhando muito mais com um conceito de pesquisa do que de simplesmente informar, como, por exemplo, o objeto da nossa análise, a revista Superinteressante; que aborda inúmeros assuntos, por se tratar de uma publicação científica de temas gerais, e isso que motivou essa pesquisa. Afinal, quais são os critérios de "publicabilidade" de uma revista como a Super?

\section{Análises e Redação Sintética dos Resultados}

Partiremos agora para a nossa análise. Como forma de segmentar o nosso objeto, optamos, como já foi dito, dentre o universo de reportagens e matérias de cada edição da revista, por analisar apenas os conteúdos com chamada na capa, pois acreditamos que seja na capa que esteja o melhor de cada edição. E isso ocorre com qualquer publicação, se a capa não agradar ao leitor, muito provavelmente ele não a irá comprar. 
Como forma de facilitar a visualização dos resultados obtidos, vamos apresentá-los em forma de tabela, onde citaremos o exemplar analisado e os critérios encontrados.

Tabela 1 - Número de matérias enquadradas nos critérios de noticiabilidade por edição

\begin{tabular}{|l|c|c|c|c|c|c|}
\hline Critérios verificados/Edição & jun/08 & jul/08 & set/08 & out/08 & nov/08 & dez/08 \\
\hline Atualidade & 2 & & & 1 & 2 & 2 \\
\hline Quantidade de pessoas envolvidas & 1 & & 2 & 3 & 2 & 2 \\
\hline Frequência & 1 & & & & & \\
\hline Capacidade de entretenimento & 2 & & 1 & & & 1 \\
\hline Impacto sobre a nação & 1 & 1 & & & & 1 \\
\hline Interesse & 2 & 2 & 2 & 1 & & 1 \\
\hline Qualidade & 1 & 1 & & & 1 & \\
\hline $\begin{array}{l}\text { Nível hierárquico dos indivíduos } \\
\text { envolvidos }\end{array}$ & & & & & 1 & \\
\hline Interesse humano & & & 1 & 1 & 1 & \\
\hline
\end{tabular}

Fonte: $\mathrm{O}$ autor.

\section{Considerações Finais}

Assim chegamos ao objetivo da nossa pesquisa, que era descobrir, através de análise de conteúdo de exemplares, em que medida os critérios de noticiabilidade são utilizados por uma revista mensal, no caso, a revista Superinteressante. Os resultados obtidos com essas análises nos trouxeram a uma conclusão oposta ao que era esperado, uma vez que partimos do princípio que os critérios de noticiabilidade seriam mais utilizados pelos meios midiáticos mais imediatos, como jornais e telejornais, e que não seria adotado por revistas mensais, ou pelo menos não seria tão percebido, devido às suas especificidades, principalmente devido a distância temporal. Desta forma, não houve a necessidade de descobrirmos algum critério de "publicabilidade", uma vez que os critérios já existentes abarcaram satisfatoriamente até mesmo este veículo mensal.

O critério mais utilizado pela revista certamente condiz com a tiragem da revista, e sua abrangência nacional: quantidade de pessoas envolvidas, que se fez mais visível em 11 das 40 matérias analisadas. Entendemos que para uma revista com uma tiragem média de 420 mil exemplares espalhados pelo Brasil inteiro, matérias que busquem abranger um 
maior número de pessoas sejam sempre melhores do que aquelas que visem a um público muito específico, se fazendo necessárias para atender a um público heterogêneo. Também por este motivo, outro critério que foi utilizado, mas em menor proporção, o do impacto sobre a nação, também se enquadra nessas características, pois também diz respeito a um elevado número de pessoas, e leva este título devido ao seu conteúdo estar relacionado a questões territoriais e de soberania nacional.

O que mais chamou atenção em nossos resultados foi que o segundo critério mais adotado pela revista, 8 vezes verificado, é o da atualidade, justamente o que julgamos que seria o menos utilizado. Observamos também que, embora trate de assuntos com uma distância temporal maior em relação aos outros meios, a revista segue fielmente Scalzo (2006, p. 101), quando diz que uma revista que tratar de assuntos que já foram o mês inteiro tratados pelos outros meios deve abordar o assunto de forma profunda, apresentando informações que o leitor ainda não sabe, como o histórico do fato, por exemplo, o que na maioria das vezes é ignorado no jornalismo diário; recomendações estas consideradas básicas para uma publicação mensal.

Algumas matérias puderam ser enquadradas no critério de interesse. Como o próprio nome da publicação já diz (Superinteressante), matérias com esse critério são bastante recorrentes na revista, e tomam forma em assuntos que os editores consideram que seu público se interessará, caracterizando assim um critério bastante subjetivo.

Vale destacar aqui que os critérios apontados em nossas análises são os mais evidentes, não que sejam os únicos. Em várias matérias encontramos diferentes critérios, sendo difícil encontrar alguma matéria que tenha se pautado apenas por um, mas, para seguir com a sistemática da nossa pesquisa, apontamos apenas o mais evidente em cada matéria. E isso também ocorre com praticamente qualquer produto jornalístico, onde dificilmente será verificado apenas um critério de noticiabilidade.

\section{Referências Bibliográficas}

HOHLFELDT, A. Hipóteses contemporâneas de pesquisa em comunicação. In: HOHLFELDT, A; MARTINHO, L.C.; FRANÇA, V.V. (organizadores). Teorias da comunicação: conceitos, escolas e tendências. 8. ed. Petrópolis, RJ: Vozes, 2008. 
KUNCZIK, M. Conceitos de jornalismo. 2 ed. $1^{\text {a }}$ reimpressão. São Paulo: Editora da Universidade de São Paulo, 2002.

NOBLAT, Ricardo. A arte de fazer um jornal diário. 7 ed. $2^{a}$ reimpressão. São Paulo: Contexto, 2008.

SCALZO, M. Jornalismo de revista. 3. ed. São Paulo: Contexto, 2006.

TRAQUINA, N. Teorias do Jornalismo: Porque as notícias são como são. v. 1. 2. ed. Florianópolis: Insular, 2005.

Teorias do Jornalismo. A tribo jornalística - uma comunidade interpretativa transnacional. v. 2. 2. ed. Florianópolis: Insular, 2008.

VILAS BOAS, S. O estilo magazine: o texto em revista. São Paulo: Summus, 1996.

WOLF, M. Teorias da comunicação. 8. ed. Lisboa: Editora Presença. 2003. 